\title{
The Well-Being of Stay Behind Family Members in Migrant Households
}

Citation for published version (APA):

Haagsman, K., \& Mazzucato, V. (2020). The Well-Being of Stay Behind Family Members in Migrant Households. In T. Bastia, \& R. Skeldon (Eds.), Routledge Handbook of Migration and Development (1 ed., pp. 181-190). Routledge/Taylor \& Francis Group. https://doi.org/10.4324/9781315276908-16

Document status and date:

Published: 26/02/2020

DOI:

10.4324/9781315276908-16

Document Version:

Publisher's PDF, also known as Version of record

Document license:

Taverne

Please check the document version of this publication:

- A submitted manuscript is the version of the article upon submission and before peer-review. There can be important differences between the submitted version and the official published version of record.

People interested in the research are advised to contact the author for the final version of the publication, or visit the DOI to the publisher's website.

- The final author version and the galley proof are versions of the publication after peer review.

- The final published version features the final layout of the paper including the volume, issue and page numbers.

Link to publication

\footnotetext{
General rights rights.

- You may freely distribute the URL identifying the publication in the public portal. please follow below link for the End User Agreement:

www.umlib.nl/taverne-license

Take down policy

If you believe that this document breaches copyright please contact us at:

repository@maastrichtuniversity.nl

providing details and we will investigate your claim.
}

Copyright and moral rights for the publications made accessible in the public portal are retained by the authors and/or other copyright owners and it is a condition of accessing publications that users recognise and abide by the legal requirements associated with these

- Users may download and print one copy of any publication from the public portal for the purpose of private study or research.

- You may not further distribute the material or use it for any profit-making activity or commercial gain

If the publication is distributed under the terms of Article $25 \mathrm{fa}$ of the Dutch Copyright Act, indicated by the "Taverne" license above, 


\title{
THE WELL-BEING OF STAY BEHIND FAMILY MEMBERS IN MIGRANT HOUSEHOLDS
}

\author{
Karlijn Haagsman and Valentina Mazzucato
}

\section{Introduction}

Until the turn of the century, most work on migration focused on migrants and the effects migration has on the host society. But for every migrant that leaves his or her origin country, there are also family members and loved ones that he/she 'leaves behind'. This geographic separation has well-being consequences on both sides and involves complex transnational caring arrangements when it concerns dependent children or elderly (Toyota et al. 2007). Bryceson and Vuorela (2002) highlighted the existence of these so-called transnational families in 2002 and started a sub-field of transnational migration scholarship that turned to studying how families continue to function over great distances.

The effects of migration on origin countries was researched before the sub-field of transnational family scholarship evolved. Starting with the Manchester school in 1947, anthropologists studied how migration to the Copper Belt in southern Africa affected communities of origin (Epstein 1992; Mayer 1962; Schapera 1947). Yet, most of this literature, and the subsequent field of migration and development studies focused on the realm of development, mostly at the macro-level and on economic gains. It looked at households as an entire unit not distinguishing the effects on individual members (Mazzucato 2015). In short, until the turn of the century there was little scholarly attention on the experiences of individual members 'left behind' by migrants. Only around 3.4 per cent of the world's population is classified as an international migrant at any one time (UNDESA 2017), but those affected by migration, or those 'left behind', are considerably more numerous. The relative lack of studies that address the experience of the 'left behind' is noteworthy, particularly because studying the 'left behind' can give important insights into the lives of migrants as well (Mazzucato 2011).

Starting in the 2000s, the literature on transnational families brought the 'left behind' into scholarly view. Transnational families are those in which one or more members of a family live in another country or region for extended periods of time. When members migrate, they remain connected to their home communities and family members and engage in family practices and maintain relationships despite geographical separation (Bryceson and Vuorela 2002; Glick Schiller et al. 1992). This was a break from most literature in 
family studies which focused on families living together or separated through divorce, crisis, or death (Mazzucato and Schans 2011; Suarez-Orozco et al. 2002). Despite the emphasis of transnational family studies on the importance of considering the whole family, even those who are separated by great distances, most of the early work still focused on the migrants in these families and how they coped with the separation. Since the 2010s, however, this literature has started to focus on the effects of migration on the 'left behind'. This chapter will provide an overview of this recent literature.

The term 'left behind' is quite broad. Most studies focus on nuclear family members, but others include extended family and friends, while others even go as far as to include the communities migrants leave behind (Nguyen et al. 2006). The term 'left behind' is also ambiguous because it has a negative condition: that of abandonment or neglect and implicitly depicts the 'left behind' as passive victims who are forced to stay in the country of origin and do not have any say (Archambault 2010; Nguyen et al. 2006). As we will see in this chapter, this is far from true. Therefore, increasingly, researchers are moving away from the term and use, for example, 'stayers', to refer to the 'left behind'. We will use the term stayers but when the literature itself uses the term 'left behind' we employ it in our review yet denote it in quotation marks to remind the reader that this is a term with implicit meanings with which we do not necessarily agree.

This review focuses on the two groups that are most often considered in the literature: children and elderly parents. Although spouses and partners are also an important group of stayers, we do not discuss them here as they are discussed in Chapter 9 on gender and migration. When discussing each group, we review both qualitative anthropological and sociological in-depth studies focusing on a small number of cases, as well as quantitative sociological, demographic, and psychological literature based on large samples. We structure the review around the main topic that these studies investigate: the effect on stayers' well-being, broadly defined and including mental and physical health, education, social behaviour, household labour, and economic security, and look into important mediating and explanatory factors.

\section{Children}

Several million children are estimated to stay at origin while one or both of their parents migrate overseas. Although exact numbers are unknown, estimates illustrate the extent of this phenomenon for some developing countries. It has been estimated that up to 1 million Sri Lankan children have a migrant mother abroad (Save the Children 2006); 9 million Filipino minors (27 per cent of all Filipino children) have at least one parent working abroad (Kakammpi in Parreñas 2005); and 21 per cent of Dominican children and one in six children under 18 in El Salvador, Mexico, Puerto Rico, and Nicaragua live apart from a migrant parent (Dewaard et al. 2018). This has not gone unnoticed by NGOs and governments who are afraid that parent-child separation can lead to adverse outcomes for children, especially if they are separated from their mothers. Moreover, next to transnational family scholars, family sociologists and child psychologists have shown increasing concern and have investigated the well-being of these children. Most studies refer to children as being under the age of 18 .

Most studies find that parental migration has negative impacts on children's overall wellbeing. Several anthropological studies found that transnational parent-child separation can lead to conflict and resentment (Coe 2008; Dreby 2007; Schmalzbauer 2004), depressive symptoms, loneliness, and feelings of abandonment (Dreby 2010; Levitt 2001; Parreñas 2005; Pribilsky 2001), and behavioural problems (Moran-Taylor 2008; Schmalzbauer 2004; Smith 
2006), which can also affect the migrant parents' well-being. For example, an anthropological study on Mexican children reports that some felt abandoned and developed strategies to 'punish' their parents for leaving them behind such as refusing to speak to them on the phone or refusing to accept their parent's parental authority (Dreby 2007). Furthermore, some studies indicated that educational aspirations and performance of stayer children could also be affected (Dreby 2010; Moran-Taylor 2008).

More recently, child psychology and family sociology studies have looked into the effects of parental migration on children's well-being using survey data. Generally, these quantitative studies have corroborated the findings in the qualitative literature that separation can affect the child negatively. They find that parental migration can affect children's emotional health (Jordan and Graham 2012; Mazzucato et al. 2015; Wen and Lin 2012), physical health, and health behaviour (Salah 2008; Wen and Lin 2012), and social behaviour (Fan et al. 2010). Likewise, parental migration can affect school behaviour, educational outcomes, and aspirations negatively (Battistella and Conaco 1998; Mckenzie and Rapoport 2007; Robles and Oropesa 2011; Wen and Lin 2012). However, conversely through remittances children can be sent to better schools which can lead to the better educational performance of these children (Kandel and Kao 2001; Lu 2012).

Although much of the literature concludes that the overall well-being of 'left behind' children might be negatively affected by parental migration, some studies find no effect or even a positive effect of migration on children's emotional well-being (Asis 2006; Cebotari et al. 2017; Wen and Lin 2012), physical health and nutrition (Asis 2006; Carling and Tønnessen 2013; Cebotari et al. 2017), and education (Antman 2012; Cebotari and Mazzucato 2016; Kandel and Kao 2001). More importantly, recent literature points to the importance of specific characteristics of the transnational child-raising arrangement and points to factors that mediate this relation and/or explain it. As such these studies nuance the findings of the poor well-being of stayer children and show the importance of taking micro- and meso-level characteristics into account. In general, three conditions are found to be of importance: 1) communication; 2) the environment; and 3) the structure of the transnational child-raising arrangement.

First, communication between parent and child is very important for the well-being of both (Dreby 2010; Madianou and Miller 2011; Parreñas 2005; Zentgraf and Chinchilla 2012), as irregular or little contact can be seen by the child as disinterest or abandonment (Suarez-Orozco et al. 2002; Zentgraf and Chinchilla 2012). And, as remittances are 'the currency of contact across borders' (Dreby and Adkins 2010, 680), not being able to send these because of low socio-economic well-being or undocumented status can affect relationships between migrant parents, caregivers, and children (Dreby 2006; Haagsman 2015; Pribilsky 2004), and hence affect the well-being of the 'left behind' child.

Second, the physical and social environment in which the child grows up plays a major role. Quantitative studies find that socio-economic status, care arrangements, child's psychological traits, parent's and caregiver's education, and teacher involvement are important mediators in the relation between child well-being and parental migration (Fan et al. 2010; Wen and Lin 2012). Potential negative effects on children's well-being can be exacerbated when children are left in inadequate care, get little parental guidance, and have gained more responsibilities in the household because of the absence of one or both parents (Vanore 2015).

Last, but not least, how the transnational child-raising arrangement is set up is of great significance: who takes care of the child and who has migrated? Although results are not conclusive (Graham and Jordan 2011; He et al. 2012; Mazzucato et al. 2015; Vanore et al. 
2015), most of these studies concur that children are worse off when mothers migrate (Dreby 2010; Gao et al. 2010; Jia and Tian 2010; Liu et al. 2009; Parreñas 2005; Wen and Lin 2012). Different reasons are given. Some authors argue that it is because of the special bond children have with their mothers (Parreñas 2008) and/or because of gender norms in place that create different expectations from mothers and fathers. While fathers are expected to provide mostly financial care, mothers are expected to provide emotional care, which is more difficult to provide across borders (Dreby 2006, 2007; Hondagneu-Sotelo and Avila 1997; Parreñas 2005). Therefore, children can feel more abandoned when their mothers migrate. Others argue that these differences arise because mother-away and father-away families are differently structured and face different structural constraints making migrant mothers more vulnerable (Caarls et al. 2018; Hondagneu-Sotelo and Avila 1997; Parreñas 2001). For instance, Mazzucato et al. (2015) found that migrant mothers, possibly through their structural constraints, 'leave' their children in less stable care arrangements than migrant fathers, which leads to the next important factor in the transnational child-raising arrangement: the caregiver of the child.

Caregivers are essential in helping children cope with the separation and alleviating emotional hardships and are important mediators in the relation between migrant parent and child (Hoang and Yeoh 2012; Schmalzbauer 2008; Suarez-Orozco et al. 2002), making the relationship between migrant parent and caregiver essential. If the relationship between caregiver and parent is strained because they are divorced or separated this harmfully affects the migrant parent-child relationship (Dreby 2006; Haagsman and Mazzucato 2014; Nobles 2011). Additionally, the specific characteristics of the caregiver are also important for the well-being of the child, such as the caregiver's mental health (Jordan and Graham 2012), human capital (Fan et al. 2010; Vanore et al. 2015), gender, and position in the family. For example, children might reproach their parents if they perceive the care provided as bad (Poeze and Mazzucato 2013), which can happen especially if the caregiver is not one of the parents. Moreover, children in the care of their grandparents do less well than children whose caregiver is one of the parents (Jia and Tian 2010) Although uncommon, nonrelatives can be caregivers (Dankyi 2015), although Fan et al. (2010) find that children in such care are more prone to emotional and behavioural problems.

\section{Elderly}

Migration can also affect elderly stayers. This is an important category as the elderly compose a vulnerable group in the Global South, of which a relatively large share is living in poverty. Emigration can lead to more elderly persons living alone (Du et al. 2004; Kanaiaupuni 2000), challenging the traditional role of the family in elderly care (Guo et al. 2009). As with children, ageing parents often need care which requires physical presence and close geographic proximity (King and Vullnetari 2006). Indeed, it has even been found that care of elderly or sick parents is often a reason for return migration (King et al. 1983). And, as with children, good relationships, and caregiving practices can be established across borders. Despite not living geographically close, migrant children are often actively involved in the caring process and often try to provide for their elderly parents through regular visits, remittances, gifts, and calls to their parents and their caretakers (Baldock 2000; Zechner 2008; Zimmer and Knodel 2013).

Adult children who migrate overseas or to urban areas often provide an important source of income for elderly parents (Guo et al. 2009; Knodel et al. 2010; Knodel and Saengtienchai 2007). Most studies find that the economic well-being of the elderly substantially 
increases with migration (Du et al. 2004; Guo et al. 2009; Knodel and Saengtienchai 2007), although in exceptional cases, such as in rural Albania, it was found to lead to more economic insecurity (King and Vullnetari 2006). Yet, migrant children have difficulties providing other support that the elderly may need such as food, help with household chores, and assistance in the businesses of their elderly parents (Du et al. 2004; Knodel et al. 2010). Moreover, daily care for the elderly, especially if they are ill or disabled, requires regular physical presence which migrants cannot provide. Therefore, the elderly who are in need of physical care can be especially vulnerable when their children migrate (Guo et al. 2009).

Mental and physical health effects can also arise. Various studies have found that the staybehind elderly experience a greater risk of psychosocial and emotional distress, loneliness, and depression (Adhikari et al. 2011; De Soto et al. 2002; King and Vullnetari 2006). In addition, the physical health of the stay-behind elderly can also be affected. Antman (2010) found that in Mexico, elderly persons who had a child abroad were more likely to suffer from a heart attack or stroke. Through the migration of their children, elderly people lose their social support, as migrant children cannot assist their elderly parents directly in times of crisis, such as illness or moments of weak mental health. Studies report even worse effects for elderly in rural areas where the remote and often rough location makes them already more prone to isolation and out-migration is often high (King et al. 2003; King and Vullnetari 2006). However, again results are inconclusive with some studies finding no effects or even positive effects on health (Adhikari et al. 2011; Guo et al. 2009; Kuhn et al. 2011). For example, Abas et al. (2009) found no relation between children's out-migration and levels of depression amongst elderly parents in rural Thailand. Even more so, when taking parental characteristics, social support, health, and wealth into account, the elderly with migrant children were less often depressed than their counterparts who had non-migrant children.

On the other hand, while migrant children cannot provide direct care, it does not mean they are not involved in their parent's health care. The elderly with migrant children can make better use of health services (Adhikari et al. 2011) because their migrant children may have better access to information, set up specific savings schemes that allow parents to receive financing for their health needs and can send remittances when parents are in need of treatment (Knodel et al. 2010; Mazzucato 2008). Moreover, if elderly parents are really ill, migrant children often decide to visit and provide the care they need or return if their situation allows it (King et al. 1983; Knodel et al. 2010). Again, communication is key to the well-being of stayer parents. But how often and how long children call is also dependent on the economic and legal status of the migrant child and, if children cannot visit, they sometimes ask other migrants to visit and bring remittances and gifts (King and Vullnetari 2006).

While remittances can improve elderly people's material and emotional well-being (Guo et al. 2009; Silverstein et al. 2006), they are also an unstable source of income. King and Vullnetari (2006) found that remittances tend to slow down, first, when migrant children have their own children and, second, the longer migrant children are away. Mazzucato (2008) found that elderly people in Ghana actively seek to care for their migrant children's children, as a way to gain access to material care, such as household chores, and to ensure a steady flow of remittances, knowing that their adult child will be more likely to send remittances for their own child.

How care for elderly parents is organised depends on how far the migrant is located from the elderly parent, the resources, such as remittances and housing, the migrant has available for caregiving, cultural filial norms, and resulting feelings of obligation, and the (care) provisions of the origin country (Baldassar 2007; Zechner 2008). In addition, the 
well-being of parents also depends on whether, besides the migrant child, they have other non-migrant children who can provide daily care, which is often the case (Knodel et al. 2010).

The elderly are not only care receivers, they can also be essential care providers in the post-migration household, which can increase their workload (Gassmann et al. 2013). For example, they can be asked to take care of property or administrative issues while their migrant child is away (Mazzucato 2008). Moreover, elderly are sometimes asked by their migrant children to take care of their grandchildren while they are abroad. This could be for a short period until the migrant is settled and reunifies with his/her child abroad, but this could also be for an extended period of time. Chang et al. (2011) found that elderly people in Chinese migrant households dedicated significantly more time to domestic work and subsistence labour than elderly people in non-migrant households. For some of the elderly, the childcare burden is difficult to manage because of limited resources, their old age, their worries over the child's well-being, and their heightened responsibility, which can lead to decreased well-being (Dankyi et al. 2017; Salah 2008; Yarris 2014).

\section{Conclusion}

This chapter has shown that migration impacts people in origin countries in ways other than the economic even if the latter has been the main focus of studies on the impact of migration on origin countries. Yet family members who remain in the country of origin can be impacted in various other domains that relate to their general well-being, including health, psychological well-being, education, aspirations, social behaviour, and household labour. The various studies reviewed here, showed that the effect of migration on overall well-being is not clear cut. As gender and family norms are different across the world and conditions of migration vary, so do the effects of migration on stayers. Therefore, it is indispensable to take contextual factors into account in the study of stayers. This includes norms, structural factors such as the socio-economic status of the family and who migrates.

Moreover, although cross-country analyses have been scarce, they have shown that the macro-level, too, is of importance for the well-being of stayers. For example, the few crosscountry comparisons that exist find that the destination country of migrants matters for the well-being of stayers (Graham et al. 2015; Mazzucato et al. 2015). Migration policies in countries of destination are important because transnational separations can be the result of strict policies that make it difficult for families to reunify. This in turn affects the well-being of both migrants and stayers (Coe 2014; Dreby 2010; King and Vullnetari 2006). Other kinds of policies matter as well, such as those affecting which sectors of the economy migrants can work in and whether they are able to gain stable employment (Dito et al. 2017). Finally, the conditions at home also matter, such as whether a country is recovering from civil strife (Mazzucato et al. 2015).

Importantly, this chapter has shown that migration does not necessarily impact stayers negatively, and at times can even have positive effects. Some NGOs, policymakers, and academics, stress negative effects. Yet while negative effects exist, they do not depict the full story and only portraying the negative side can stigmatise stayers and migrants. It is important for research to further investigate the circumstances under which migration leads to negative consequences for stayers. It is through answering this question that research can guide policymakers to address the well-being of stayers. 


\section{References}

Abas, M. A., Punpuing, S., Jirapramukpitak, T., Guest, P., Tangchonlatip, K., Leese, M., and Prince, M. (2009) "Rural-urban migration and depression in ageing family members left behind", British Journal of Psychiatry, 195, 54-60.

Adhikari, R., Jampaklay, A., and Chamratrithirong, A. (2011) "Impact of children's migration on health and health care-seeking behavior of elderly left behind", BMC Public Health, 11, 143.

Antman, F. M. (2010) "Adult child migration and the health of elderly parents left behind in Mexico", The American Economic Review, 100, 205-208.

Antman, F. M. (2012) "Gender, educational attainment, and the impact of parental migration on children left behind", Journal of Population Economics, 25, 1187-1214.

Archambault, C. S. (2010) "Women left behind? Migration, spousal separation, and the autonomy of rural women in Ugweno, Tanzania”, Signs, 35, 919-942.

Asis, M. M. B. (2006) "Living with migration", Asian Population Studies, 2, 45-67.

Baldassar, L. (2007) "Transnational families and aged care: The mobility of care and the migrancy of ageing", Journal of Ethnic and Migration Studies, 33, 275-297.

Baldock, C. (2000) "Migrants and their parents: Caregiving from a distance", Journal of Family Issues, 21, 205-224.

Battistella, G. and Conaco, M. C. G. (1998) “The impact of labour migration on the children left behind: A study of elementary school children in the Philippines", Sojourn: Journal of Social Issues in Southeast Asia, 13, 220-241.

Bryceson, D. and Vuorela, U. (2002) The transnational family, New European frontiers and global networks, Berg, Oxford \& New York.

Caarls, K., Haagsman, K., Kraus, E. K., and Mazzucato, V. (2018) “African transnational families: Crosscountry and gendered comparisons”, Population, Space and Place, 24, e2162.

Carling, J. and Tønnessen, M. (2013) "Fathers' whereabouts and children's welfare in Malawi”, Development Southern Africa, 30, 724-742.

Cebotari, V. and Mazzucato, V. (2016) "Educational performance of children of migrant parents in Ghana, Nigeria and Angola", Journal of Ethnic and Migration Studies, 42, 834-856.

Cebotari, V., Mazzucato, V., and Siegel, M. (2017) "Child development and migrant transnationalism: The health of children who stay behind in Ghana and Nigeria", The Journal of Development Studies, 53, 444-459.

Chang, H., Dong, X.-Y., and Macphail, F. (2011) "Labor migration and time use patterns of the left-behind children and elderly in rural China", World Development, 39, 2199-2210.

Coe, C. (2008) "The structuring of feeling in Ghanaian transnational families", City \& Society, 20, 222-250.

Coe, C. (2014) The scattered family: Parenting, African migrants, and global inequality, University of Chicago Press, Chicago, IL.

Dankyi, E. (2015) Transnational Child Raising Arrangements: An Ethnographic study of Transnational Caregivers in Ghana, $\mathrm{PhD}$ dissertation, University of Ghana.

Dankyi, E., Mazzucato, V., and Manuh, T. (2017) "Reciprocity in global social protection: Providing care for migrants' children", Oxford Development Studies, 45, 80-95.

De Soto, H., Gordon, P., Gedeshi, I., and Sinoimeri, Z. (2002) Poverty in Albania. A qualitative assesment. World Bank Technical Paper 520, World Bank, Washington, DC.

Dewaard, J., Nobles, J., and Donato, K. M. (2018) "Migration and parental absence: A comparative assessment of transnational families in Latin America", Population, Space and Place, 24, e2166.

Dito, B., Mazzucato, V., and Schans, D. (2017) "The effects of transnational parenting on the subjective health and well-being of Ghanaian migrants in The Netherlands", Population, Space and Place, 23, e2006.

Dreby, J. (2006) "Honor and virtue - Mexican parenting in the transnational context", Gender E Society, $20,32-59$.

Dreby, J. (2007) “Children and power in Mexican transnational families”, Journal of Marriage and Family, $69,1050-1064$.

Dreby, J. (2010) Divided by borders. Mexican migrants and their children, University of California Press, Berkeley, CA.

Dreby, J. and Adkins, T. (2010) "Inequalities in transnational families”, Sociology Compass, 4, 673-689.

Du, P., Ding, Z., Li, Q., and Gui, J. (2004) "The impact of out labor migration on the elderly stayers in rural areas", Population Research, 28, 44-52. 
Epstein, A. L. (1992) Scenes from African urban life: Collected copperbelt papers, Edinburgh University Press, Edinburgh.

Fan, F., Su, L., Gill, M. K., and Birmaher, B. (2010) "Emotional and behavioral problems of Chinese left-behind children: A preliminary study", Social Psychiatry \& Psychiatric Epidemiology, 45, 655-664.

Gao, Y., Li, L. P., Kim, J. H., Congdon, N., Lau, J., and Griffiths, S. (2010) "The impact of parental migration on health status and health behaviours among left behind adolescent school children in China", BMC Public Health, 10, 56.

Gassmann, F., Siegel, M., Vanore, M., and Waidler, J. (2013) The impact of migration on children left behind in Moldova. UNU-MERIT Working Papers, Maastricht.

Glick Schiller, N., Basch, L., and Blanc-Szanton, C. (1992) "Transnationalism - A new analytic framework for understanding migration", Annals of the New York Academy of Sciences, 645, 1-24.

Graham, E. and Jordan, L. P. (2011) "Migrant parents and the psychological well-being of left-behind children in Southeast Asia", Journal of Marriage and Family, 73, 763-787.

Graham, E., Jordan, L. P., and Yeoh, B. S. A. (2015) "Parental migration and the mental health of those who stay behind to care for children in South-East Asia", Social Science \& Medicine, 132, 225-235.

Guo, M., Aranda, M. P., and Silverstein, M. (2009) "The impact of out-migration on the inter-generational support and psychological wellbeing of older adults in rural China", Ageing $\&$ Society, 29, 1085-1104.

Haagsman, K. (2015) Parenting across Borders: Effects of Transnational Parenting on the Lives of Angolan and Nigerian Migrant Parents in the Netherlands. PhD dissertation, Maastricht University, Maastricht.

Haagsman, K. and Mazzucato, V. (2014) "The quality of parent-child relationships in transnational families: Angolan and Nigerian migrant parents in The Netherlands", Journal of Ethnic and Migration Studies, 40, 1677-1696.

He, B., Fan, J., Liu, N., Li, H., Wang, Y., Williams, J., and Wong, K. (2012) "Depression risk of 'leftbehind children' in rural China", Psychiatry Research, 200, 306-312.

Hoang, L. A. and Yeoh, B. S. A. (2012) "Sustaining families across transnational spaces: Vietnamese migrant parents and their left-behind children", Asian Studies Review, 36, 307-325.

Hondagneu-Sotelo, P. and Avila, E. (1997) “I'm here, but I'm there': The meanings of Latina transnational motherhood", Gender \& Society, 11, 548-571.

Jia, Z. and Tian, W. (2010) "Loneliness of left-behind children: A cross-sectional survey in a sample of rural China", Child: Care, Health and Development, 36, 812-817.

Jordan, L. P. and Graham, E. (2012) "Resilience and well-being among children of migrant parents in South-East Asia", Child Development, 83, 1672-1688.

Kanaiaupuni, S. M. (2000) Leaving parents behind: Migration and elderly living arrangements in Mexico, Center for Demography and Ecology, University of Wisconsin, Madison, WI.

Kandel, W. and Kao, G. (2001) “The impact of temporary labor migration on Mexican children's educational aspirations and performance", International Migration Review, 35, 1205-1231.

King, R., Mai, N., and Dalipaj, M. (2003) Exploding the migration myths: Analysis and recommendations for the European Union, the UK and Albania, The Fabian Society and Oxfam, London.

King, R., Strachan, A., and Mortimer, J. (1983). Return migration: A review of the literature. Discussion Papers in Geography 19, Oxford Polytechnic, Oxford.

King, R. and Vullnetari, J. (2006) "Orphan pensioners and migrating grandparents: The impact of mass migration on older people in rural Albania", Ageing \& Society, 26(5), 783-816.

Knodel, J., Kespichayawattana, J., Saengtienchai, C., and Wiwatwanich, S. (2010) "How left behind are rural parents of migrant children? Evidence from Thailand", Ageing \& Society, 30, 811-841.

Knodel, J. and Saengtienchai, C. (2007) "Rural parents with urban children: Social and economic implications of migration for the rural elderly in Thailand", Population, Space and Place, 13, 193-210.

Kuhn, R., Everett, B., and Silvey, R. (2011) “The effects of children's migration on elderly kin's health: A counterfactual approach", Demography, 48, 183-209.

Levitt, P. (2001) The transnational villagers, University of California Press, Berkeley, CA.

Liu, Z., Li, X., and Ge, X. (2009) "Left too early: The effects of age at separation from parents on Chinese rural children's symptoms of anxiety and depression", American Journal of Public Health, 99, 2049-2054.

Lu, Y. (2012) "Education of children left behind in rural China", Journal of Marriage and Family, 74, 328-341.

Madianou, M. and Miller, D. (2011) "Mobile phone parenting: Reconfiguring relationships between Filipina migrant mothers and their left-behind children", New Media \& Society, 13, 457-470.

Mayer, P. (1962) "Migrancy and the study of Africans in Towns1", American Anthropologist, 64, 576-592. 
Mazzucato, V. (2008) "Transnational reciprocity: Ghanaian migrants and the care of their parents back home", In E. Alber, S. V. D. Geest, W. Geissler, and S. Whyte, eds, Generations in Africa: Connections and conflicts, LIT Verlag, Münster, 91-109.

Mazzucato, V. (2011) "Reverse remittances in the migration-development nexus: Two-way flows between Ghana and the Netherlands", Population, Space and Place, 17, 454-468.

Mazzucato, V. (2015) “Transnational families and the well-being of children and caregivers who stay in origin countries", Social Science \& Medicine, 132, 208-214.

Mazzucato, V., Cebotari, V., Veale, A., White, A., Grassi, M., and Vivet, J. (2015) "International parental migration and the psychological well-being of children in Ghana, Nigeria, and Angola", Social Science \& Medicine, 132, 215-224.

Mazzucato, V. and Schans, D. (2011) "Transnational families and the well-being of children: Conceptual and methodological challenges", Journal of Marriage and Family, 73, 704-712.

Mckenzie, D. and Rapoport, H. (2007) "Migration and education inequality in rural Mexico", Integration and Trade Journal, 24, 135-158.

Moran-Taylor, M. J. (2008) "When mothers and fathers migrate North: Caretakers, children, and child rearing in Guatemala", Latin American Perspectives, 35, 79-95.

Nguyen, L., Yeoh, B. S. A., and Toyota, M. (2006) "Migration and the well-being of the left behind in Asia", Asian Population Studies, 2, 37-44.

Nobles, J. (2011) "Parenting from abroad: Migration, nonresident father involvement, and children's education in Mexico", Journal of Marriage and Family, 73, 729-746.

Parreñas, R. S. (2001) Servants of globalization and domestic work, Stanford University Press, Stanford, CA.

Parreñas, R. S. (2005) "Long distance intimacy: Class, gender and intergenerational relations between mothers and children in Filipino transnational families", Global Networks-a Journal of Transnational Affairs, 5, 317-336.

Parreñas, R. S. (2008) “Transnational fathering: Gendered conflicts, distant disciplining and emotional gaps", Journal of Ethnic and Migration Studies, 34, 1057-1072.

Poeze, M. and Mazzucato, V. (2013) "African transnational families: Child fostering of Ghanaian youths when mothers and fathers migrate to the global North", In L. Baldassar, and L. Merla, eds, Transnational families, migration and kin-work: From care chains to care circulation, Routledge Transnationalism Series, New York, 149-169.

Pribilsky, J. (2001) "Nervios and 'modern childhood': Migration and shifting contexts of child life in the Ecuadorian Andes", Childhood, 8, 251-273.

Pribilsky, J. (2004) “"Aprendemos a convivir': Conjugal relations, co-parenting, and family life among Ecuadorian transnational migrants in New York City and the Ecuadorian Andes", Global Networks-a Journal of Transnational Affairs, 4, 313-334.

Robles, V. F. and Oropesa, R. S. (2011) "International migration and the education of children: Evidence from Lima, Peru", Population Research and Policy Review, 30, 591-618.

Salah, M. A. (2008) The impacts of migration on children in Moldova, UNICEF, New York.

Save the Children (2006) Left behind, left out. The impact on children and families of mothers migrating for work abroad, Save the Children in Sri Lanka, Colombo.

Schapera, I. (1947) Migrant labour and tribal life: A study of conditions in the Bechuanaland protectorate, Oxford University Press, London.

Schmalzbauer, L. (2004) "Searching for wages and mothering from Afar: The case of Honduran transnational families", Journal of Marriage and Family, 66, 1317-1331.

Schmalzbauer, L. (2008) "Family divided: The class formation of Honduran transnational families", Global Networks, 8, 329-346.

Silverstein, M., Cong, Z., and Li, S. (2006) "Intergenerational transfers and living arrangements of older people in rural China: Consequences for psychological well-being", The Journals of Gerontology: Series $B, 61, \mathrm{~S} 256-\mathrm{S} 266$.

Smith, R. C. (2006) Mexican New York: Transnational lives of new immigrants, University of California Press, Berkeley, CA.

Suarez-Orozco, C., Todorova, I. L. G., and Louie, J. (2002) "Making up for lost time: The experience of separation and reunification among immigrant families", Family Process, 41, 625-643.

Toyota, M., Yeoh, B. S. A., and Nguyen, L. (2007) "Bringing the 'left behind' back into view in Asia: A framework for understanding the "migration-left behind nexus"”, Population, Space and Place, 13, 157-161. 


\section{Karlijn Haagsman and Valentina Mazzucato}

Undesa (2017) International migration report 2017, UNDESA (United Nations Department of Economic and Social Affairs), New York.

Vanore, M. (2015) Family-Member Migration and the Psychosocial Health Outcomes of Children in Moldova and Georgia. PhD dissertation, Maastricht University, Maastricht.

Vanore, M., Mazzucato, V., and Siegel, M. (2015) "Left behind' but not left alone: Parental migration and the psychosocial health of children in Moldova", Social Science E Medicine, 132, 252-260.

Wen, M. and Lin, D. (2012) "Child development in rural China: Children left behind by their migrant parents and children of nonmigrant families", Child Development, 83, 120-136.

Yarris, K. E. (2014) "Pensando mucho" ("thinking too much”): Embodied distress among grandmothers in Nicaraguan transnational families", Culture, Medicine, and Psychiatry, 38, 473-498.

Zechner, M. (2008) "Care of older persons in transnational settings", Journal of Aging Studies, 22, 32-44.

Zentgraf, K. M. and Chinchilla, N. S. (2012) "Transnational family separation: A framework for analysis", Journal of Ethnic and Migration Studies, 38, 345-366.

Zimmer, Z. and Knodel, J. (2013) "Older-age parents in rural Cambodia and migration of adult children”, Asian Population Studies, 9, 156-174. 